BRAZILIAN JOURNAL

$\mathrm{OF}$

RADIATION SCIENCES

09-02 (2021) 01-23

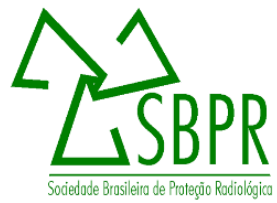

\title{
Monitoring of radionuclides in water for human consumption in the county of Angra dos Reis
}

\author{
Gonçalves $^{a}$ M.F., Ferreira ${ }^{a}$ A.C.M., Oliveira ${ }^{b}$ A.B., Almeida ${ }^{b}$ J.C.T., Cunha ${ }^{b}$ M.P.S.A. \\ ${ }^{a}$ Instituto de Radioproteção e Dosimetria - IRD, 22783-127, Rio de Janeiro, RJ, Brazil \\ ${ }^{b}$ Secretaria Municipal de Saúde de Angra dos Reis, Departamento de Vigilância Ambiental, 23906-190, Angra dos \\ Reis, RJ, Brazil \\ mary.fg@hotmail.com
}

\begin{abstract}
The radiological impact for the population living in Angra dos Reis- RJ was assessed using environmental monitoring data from radio (Ra-226 and Ra-228), lead (Pb-210), uranium (U-238), thorium (Th-232) and cesium (Cs134 and Cs-137) in water for human consumption. For this, water samples were collected and analyzed by radiometry (Cs-134 and Cs-137), radiochemical method (Ra-226, Ra-228 and Pb-210) and by mass spectrometry with inductively coupled plasma (U-238 and Th-232). From the results, it was observed that the activity concentrations found were lower than the values established by CONAMA, WHO and the Ministry of Health. It was concluded that the presence of these radionuclides in the collected waters is natural and with levels that are not harmful to health.
\end{abstract}

Keywords: environmental monitoring, water for consumption, Angra dos Reis. 


\section{INTRODUCTION}

Studies indicate that radioactivity in the environment is of great importance in monitoring radiation levels, either through direct or indirect exposure to humans [1].

Environmental radiological monitoring aims to assess, identify and control the presence of radionuclides in the environment. It is a process that consists of data collection, studies and continuous monitoring of environmental matrices, to perform measurements of external dose rates due to sources of radiation in the environment, which may interfere with exposure to ionizing radiation [1].

In Brazil, one of the places that presents environmental monitoring is the county of Angra dos Reis, which aims to analyze the possible impacts caused by the operation of the nuclear power plants around the "Almirante Álvaro Alberto Nuclear Power Plant" (CNAAA). CNAAA is located on Itaorna beach, in Angra dos Reis, approximately $130 \mathrm{~km}$ from the city of Rio de Janeiro, which is an important region from the tourist, fishing and ecological point of view [2,3].

Although the Central Nuclear (CNAAA) has an environmental control program, accompanied by the inspection bodies (IBAMA / CNEN), the city of Angra dos Reis is concerned with monitoring, radiologically, the water collection points for the well-being of the population, as it is an important item to add to the monitoring already carried out by it and to provide more information about the levels of radioactivity present in water.

The present work was carried out in the premises of the Environmental Protection Division (DIRAD) of the Institute of Radioprotection and Dosimetry (IRD/CNEN), in the laboratories of Radiochemical, Gamma Spectrometry and Mass Spectrometry (ICP-MS) [1].

The study was carried out in partnership with the Secretaria de Saúde (Health Secretariat) of Angra dos Reis, which has registered points of water supply distributed in the four districts of the Municipality of Angra dos Reis, and which were the same points used in this work [1,4].

The present study proposed to monitor the activity concentrations of radionuclides (Ra-226, Ra228, Pb-210, Cs-134, Cs-137, U-238 and Th-232) through radiochemical, radiometric and mass spectrometry with inductively coupled plasma analysis, from all water supply points registered by the city of Angra dos Reis and compare the results obtained with the values established in the 
Brazilian (Conselho Nacional do Meio Ambiente - CONAMA and Ministry of Health) and World Health Organization (WHO) criteria, regarding radioactivity [5-7].

In this study, U-238 and Th-232 were chosen to be two radionuclides from main natural radioactive series; Ra-226 and Ra-228 for being two elements considered more critical for the human consumption water and the technique used to analyze these two radionuclides allowed also the sequential separation of $\mathrm{Pb}-210$, being one more information for the work; and Cs-134 and Cs137, because are possible radionuclides released from the nuclear power plant [1].

\section{MATERIALS AND METHODS}

\subsection{Study place and sampling}

Two campaigns for collecting water for human consumption were carried out in the period in April 2016 and in November 2018. The samples were collected with the aid of plastic bottles with a capacity of $2 \mathrm{~L}$ - which were sanitized with water and deionized water - and a GPS (Geographic Positioning System) that allows determining altitude, longitude and latitude. Therefore, two liters of water were collected at each point and those points were georeferenced using a Garmin Dakota 20 GPS. The samples were collected in places of public access, outside the perimeter of the Angra dos Reis nuclear power plant, "Almirante Álvaro Alberto Nuclear Power Plant” (CNAAA). A total of 102 water samples were collected from taps or sources, in different locations in the Municipality of Angra dos Reis. After the collections, the samples were sent to the Department of Environmental Analysis (DIRAD) at the Institute of Radioprotection and Dosimetry (IRD) in the city of Rio de Janeiro.

The Municipality of Angra dos Reis consists of five districts, four of which are continental and one island - Ilha Grande. It is important to highlight that this work involved the four districts of the Municipality of Angra dos Reis for reasons of technical and financial feasibility and did not consider Ilha Grande, as it was not possible to carry out the collections due to the access limitations and the time.

At Figure 1, it is possible to observe all the points collected in each district of the Municipality of Angra dos Reis. The points of the first district (1 to 26) are highlighted by the green squares, the 
points of the second district (27 to 51) highlighted by the circles filled in yellow, the points of the third district ( 52 to 75 ) by the triangles in red and the hexagons in blue, the points of the fourth district (76 to 102).

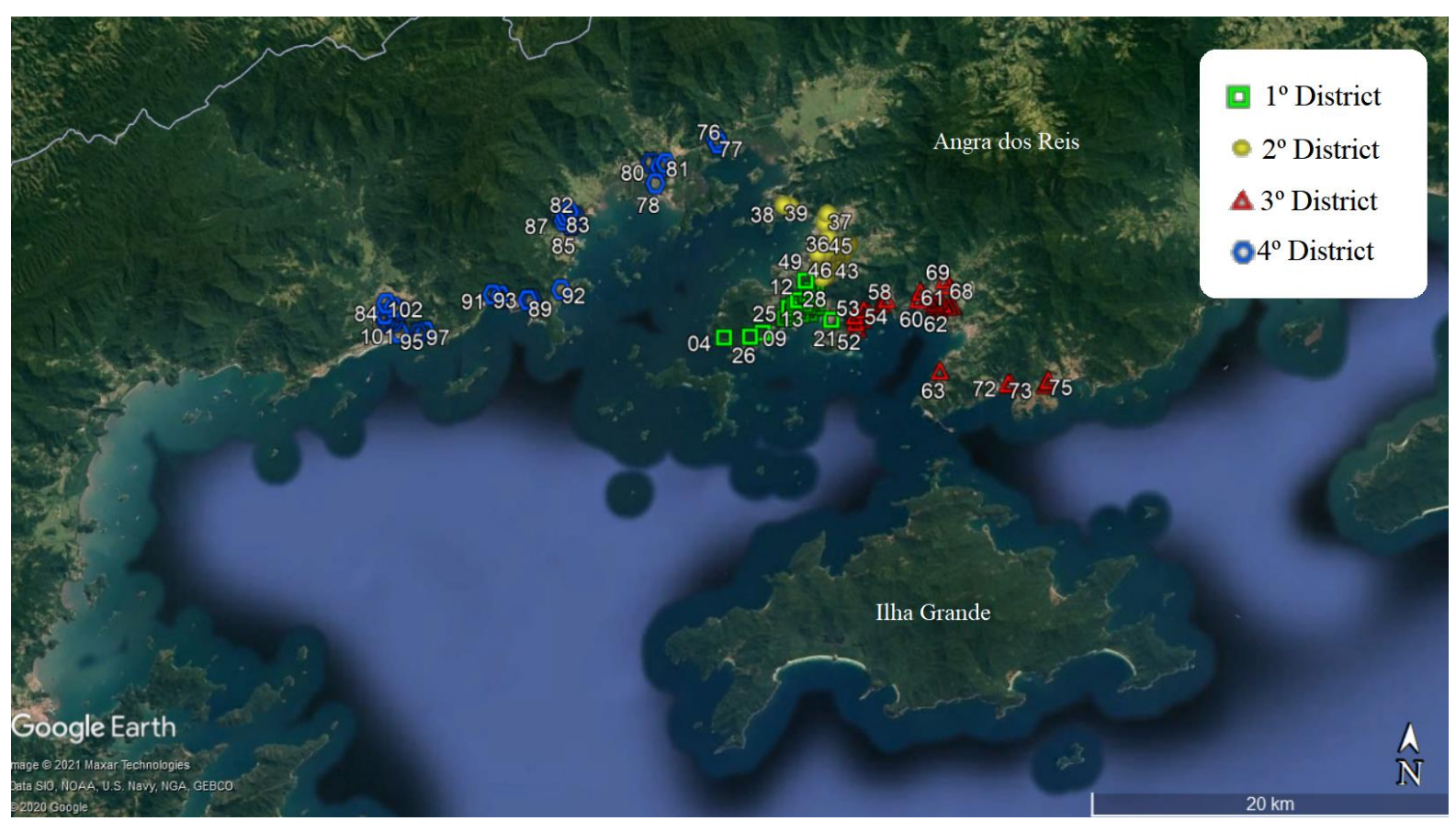

Figure 1: Map of the Municipality of Angra dos Reis with the collection points.

\subsection{Sample preparation}

The samples were filtered, using a peristaltic pump and membrane with porosity of $0.45 \mathrm{mi}$ crometer, applied to retain particles larger than membrane pores and water analysis protocols indicate its use, and then acidified ( $4 \mathrm{~mL}$ of concentrated nitric acid), in order to avoid the loss of the constituents by adhesion to the walls of the containers [1]. After this, the samples were placed in different containers for the following analyzes: radiochemical, radiometric and inductively coupled plasma mass spectrometry (ICP-MS). 


\subsection{Radiochemical}

The determinations of Ra-226, Ra-228 and Pb-210 were carried out by concentrating these elements by coprecipitation and later alpha and beta counting in a proportional counter (P1) Berthold, model LB770-1, with ultralow background. The gas used was argon-methane. The methods used were the same ones used systematically in the laboratories of the Environmental Analyzes Service, the DIRAD, the IRD/CNEN, based on the sector's procedure manuals.

The method used to determine the activity concentrations of Ra-226, Ra-228 and Pb-210 was through simultaneous precipitation, using the carriers of barium $(20 \mathrm{mg})$ and lead $(20 \mathrm{mg})$. The precipitates were filtered under vacuum and the chemical yield was determined gravimetrically.

The counting of Ra-226 and Ra-228 was done after 21 days. Ra-228 was determined by beta counting the same precipitate (the sample was covered with filter paper to shield alpha particles). The determination of lead was made after 10 days [1].

To calculate the activity concentration of Ra-226 from the measurement of total alpha activity it is used the following equation 1 [1]:

$$
A_{R a-226}=R m-R o / 60 \times R q \times Q \times E_{\alpha .} \eta_{a b s(R a-226)} x\left[1+K\left(1-e^{-\lambda R n-222 x t}\right)\right]
$$

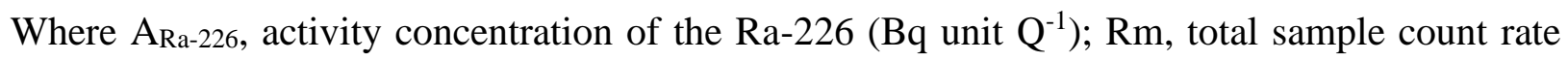
(count per minute, cpm); Ro, background count rate (cpm); Rq, chemical yield; Q, quantity of sample used for analysis [mass $(\mathrm{kg})$ or volume $(\mathrm{L})$ ]; $\mathrm{E}_{\alpha}$, alpha counting efficiency of the system, calculated with an Am-241 source $(d=2,5 \mathrm{~cm})$; $\eta_{\mathrm{abs}(\mathrm{Ra}-226)}$, Self-absorption coefficient; $\lambda_{\mathrm{Rn}-222}, \mathrm{Rn}$ 222 disintegration constant $\left(0,181 \mathrm{~d}^{-1}\right)$; $\mathrm{t}$, time elapsed between Ra precipitation and counting (days); K, coefficient expressed by the following equation 2 [1]:

$$
K=\eta_{a b s(R n-222)}+\eta_{a b s(P o-218)}+\eta_{a b s(P o-214)} / \eta_{a b s(R a-226)}
$$

To calculate the concentration of Ra-228 from the measurement of total beta activity it is used the following equation 3 [1]:

$$
A_{R a-228}=\left[R m-R o / 60 \times R q \times Q \times E_{R a-228}\right]-\left[E_{R a-226} \times A_{R a-228} \times\left(1-e^{-\lambda R n-222 \times t}\right) / E_{R a-228}\right]
$$


Where $A_{\mathrm{Ra}-228}$, activity concentration of the Ra-228 (Bq unit $\left.\mathrm{Q}^{-1}\right) ; \mathrm{R}_{\mathrm{m}}$, total sample count rate (cpm); $\mathrm{R}_{\mathrm{o}}$, background count rate (cpm); $\mathrm{R}_{\mathrm{q}}$, chemical yield; $\mathrm{Q}$, quantity of sample used for analysis (L); $\mathrm{E}_{\mathrm{Ra}-228}$, beta counting efficiency of Ra-228; $\mathrm{E}_{\mathrm{Ra}-226}$, beta counting efficiency of Ra-226; $\mathrm{A}_{\mathrm{Ra}-226}$, activity concentration of Ra-226 (Bq unit $\left.\mathrm{Q}^{-1}\right)$; t t time elapsed between Ra precipitation and counting (days); $\lambda_{\text {Rn-222, }}$ Rn-222 disintegration constant $\left(0,181 \mathrm{~d}^{-1}\right)$.

The concentration of $\mathrm{Pb}-210$ was calculated from the measurement of the total beta activity can be expressed by the following equation 4 [1]:

$$
A_{P b-210}=\left[R m-R o / 60 \times R q \times Q \times E_{\beta} \times\left(1-e^{-\lambda B i-210 x t}\right)\right]
$$

Where APb-210, activity concentration of the $\mathrm{Pb}-210\left(\mathrm{~Bq}\right.$ unit $\left.\mathrm{Q}^{-1}\right) ; \mathrm{R}_{\mathrm{m}}$, total sample count rate (cpm); $\mathrm{R}_{\mathrm{o}}$, background count rate (cpm); $\mathrm{R}_{\mathrm{q}}$, chemical yield; $\mathrm{Q}$, quantity of sample used for analysis $(\mathrm{L})$; $\mathrm{E}_{\beta}$, beta counting efficiency of the $\mathrm{Bi}-210$; $\mathrm{t}$, time elapsed between $\mathrm{PbCrO}_{4}$ precipitation and counting (days); $\lambda_{\mathrm{Bi}-210}, \mathrm{Bi}-210$ disintegration constant $\left(0,1383 \mathrm{~d}^{-1}\right)$.

The software called Analyzes was used to calculate the activities of radionuclide concentrations through the analysis reports of Ra-226, Ra-228 and $\mathrm{Pb}-210$, after counting these radionuclides [1].

\subsection{Gamma spectrometry}

It is a technique that evaluates radiation in environmental, biological and geological samples, in which the radionuclides present in the samples can be quantified through gamma rays, with no need for chemical separation [1].

This analysis was used to determine radionuclides Cs-134 and Cs-137, using ultrapure germanium detectors, HPGe. In this work, two different detectors were used, well detector and GC2020, due to the availability of the laboratory at the time. The systems of the two detectors were calibrated in energy $x$ channel with a solid point source of Eu-152. The geometry calibration was performed with a cocktail of radionuclides in a nitric acid medium in the same geometry as the samples. The geometry used in this work was a polyethylene bottle with a capacity of 1 liter. 
The counting time of every sample and background radiation was 60000 seconds, for both detectors. The GC2020 detector features a $4.0 \mathrm{keV}$ high voltage source, $20 \%$ relative efficiency and its resolution, FWHM at $1.33 \mathrm{Mev}$ of Co-60 is 2.0. The well deterctor has $3.5 \mathrm{keV}$ of voltage, $40 \%$ relative efficiency and resolution, FWHM at $1.33 \mathrm{Mev}$ of the Co-60 of 2.3. The manufacturer of both is Canberra, Inc. (USA) [1]. From the Genie 2000 software, the acquisition on the microcomputer is done with the MCA board, to read the spectrum later. The software itself reports the activity concentration and associated uncertainties of the samples based on the statistical uncertainly of peak area [8].

According to Kanisch et al., the activity of the elements present in the sample depends on the counting rate of the emitted gamma rays and to determine the average specific activity, equation 5 is used [9].

$$
A=N_{L} / E \times m \times x \times P_{\gamma}
$$

Where A, average specific radionuclide activity $\left(\mathrm{Bq} \mathrm{kg}^{-1}\right) ; \mathrm{N}_{\mathrm{L}}$, liquid count rate for radionuclide gamma ray $(\gamma)$ energy (count per second, cps); $\varepsilon$, system detection efficiency in the energy of interest; $\mathrm{m}$, mass sample $(\mathrm{kg})$; $\mathrm{t}$, counting time; $\mathrm{P}_{r}$, absolute probability of transition of the gamma ray $(\gamma)$ measured.

\subsection{Inductively coupled plasma mass spectrometry analyze}

The analyses were done using a PerkinElmer ICP-MS model NexION ${ }^{\text {TM }}$ 300D operating with high purity argon to determine U-238 and Th-232. The program used to perform inductively coupled plasma mass spectrometry analyze was Syngistix. Triplicates of each sample were made.

To execute the Performance Test the solution IRD 814-5051 (Be-Ce-Fe-In-Li-Mg-Pb-U 1 $\mu \mathrm{g} \mathrm{L}^{-}$ $\left.{ }^{1}\right)$ was inserted in the equipment. The calibration solutions were produced using the multi-element solutions from the stock: PE2 (Ce-Dy-Er-Eu-Gd-Ho-La-Lu-Nd-Pr-Sm-Sc-Tb-Th-Tm-Y-Yb), PE3 (Al-As-Ba-Be-Bi-Ca-Cd-Co-Cr-Cs-Cu-Fe-Ga-In-K-Li-Mg-Mn-Ni-Pb-Rb-Se-Na-Ag-Sr-Tl-V-U$\mathrm{Zn}$ ) and PE5 (B-Ge-Mo-Nb-P-Re-S-Si-Ta-Ti-W-Zr), which resulted in a solution with $10 \mu \mathrm{g} \mathrm{L}^{-1}$ of each element, besides a solution of the internal standard, Talium $200 \mu \mathrm{g} \mathrm{L}{ }^{-1}$, all from Perkin Elmer. The concentrations of the calibration curve ranged from 0 to $1.0 \mu \mathrm{g} \mathrm{L}^{-1}$. The calibration solutions 
were prepared with $\mathrm{HNO}_{3} 2 \%$, in order to avoid the precipitation of the standards, since the matrix of the curve is aqueous. After the Performance Test was done correctly, the calibration curve for uranium and thorium were performed. From these curves, it was possible to analyze the samples by ICP-MS.

The result of the intercomparison presented a deviation of less than $10 \%$, compared to the previously known value, thus it was possible to perform determinations by ICP-MS. In order to increase the reliability of the results and to certify the absence of contamination, readings of the blanks from the calibration curve were made, being ideal close to $0 \mu \mathrm{g} \mathrm{\textrm {L } ^ { - 1 }}$.

All the analyzes carried out participate, annually, in national (PNI) and international (ALMERA) intercomparison programs to prove the quality of the results.

\section{RESULTS AND DISCUSSION}

\subsection{Radiochemical}

\subsubsection{Determination of Ra-226 and Ra-228}

From the results of the activity concentrations, graphs were made for better visualization: Ra226, Figure 2 and Ra-228, Figure 3.

At the graphs, the concentrations of Ra-226 and Ra-228 are represented by the square markers in light blue, the continuous line refers to the detection limit of the method and the circular markers in dark blue are the values below the detection limit of the equipment. 


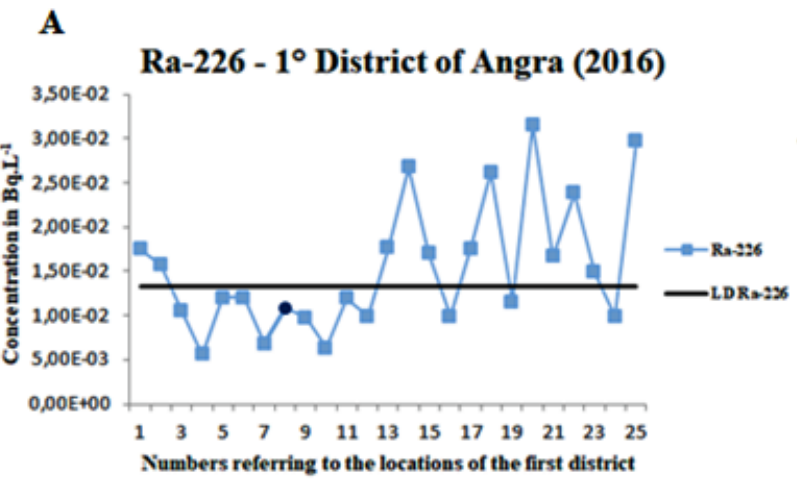

B
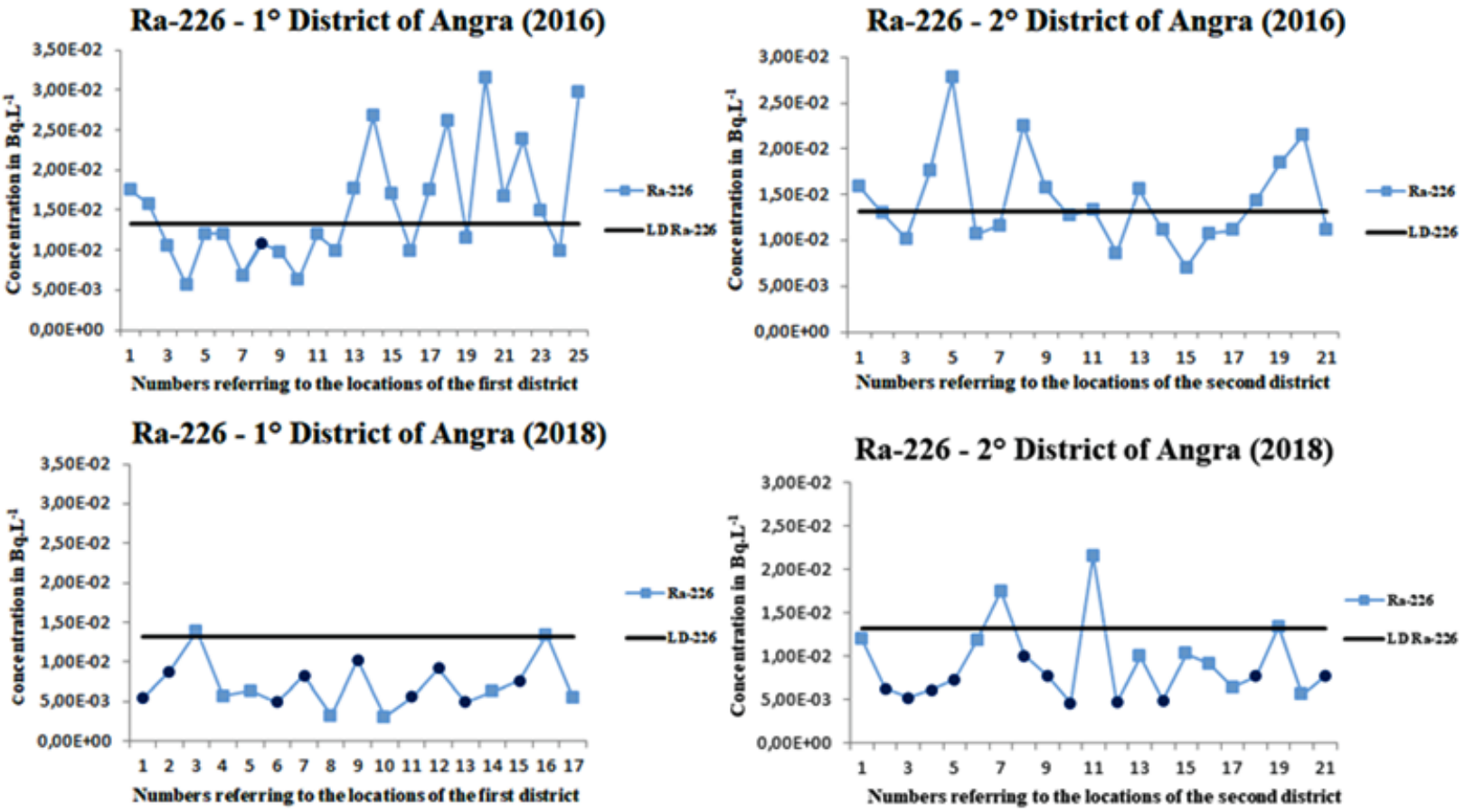

\section{C}

Ra-226 - $3^{\circ}$ District of Angra (2016)

D
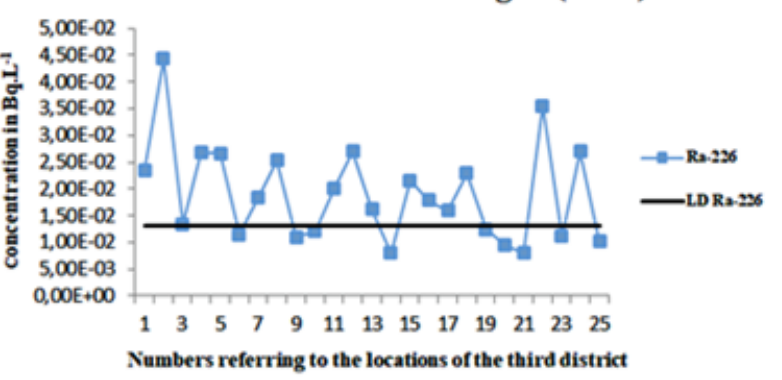

Ra-226 - $3^{\circ}$ District of Angra (2018)
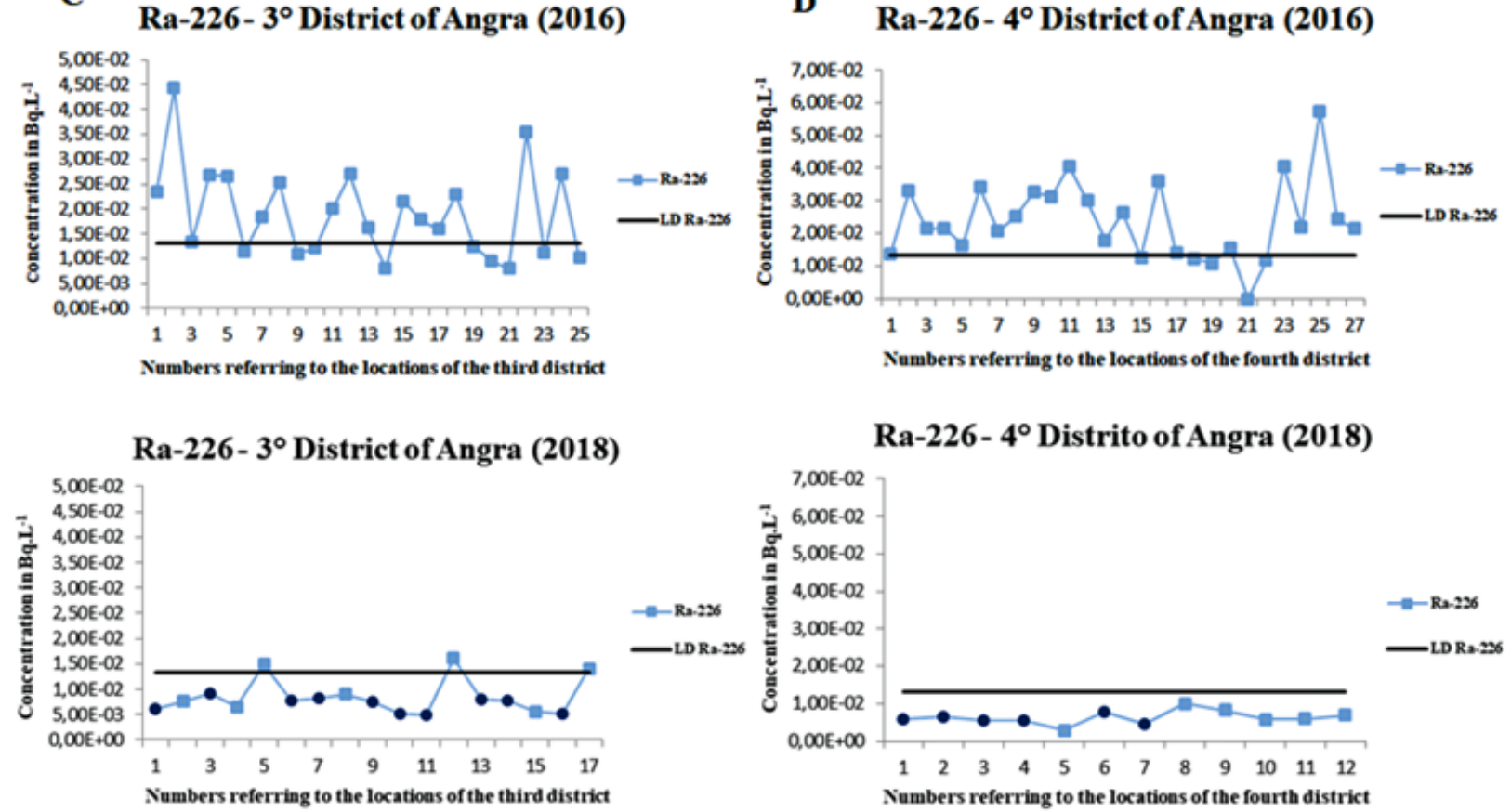

Figure 2: Graphs of Ra-226 concentrations of water samples collected in April 2016 and in November 2018 in the first district (A), the second district $(B)$, the third fistrict $(C)$ and the fourth district (D) of Angra dos Reis. 


\section{$\mathbf{A}$}

Ra-228 - $1^{\circ}$ District of Angra (2016)

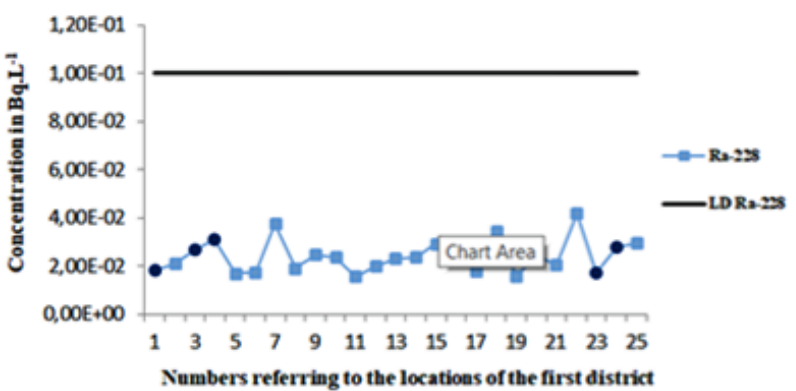

Ra-228 - $1^{\circ}$ District of Angra (2018)

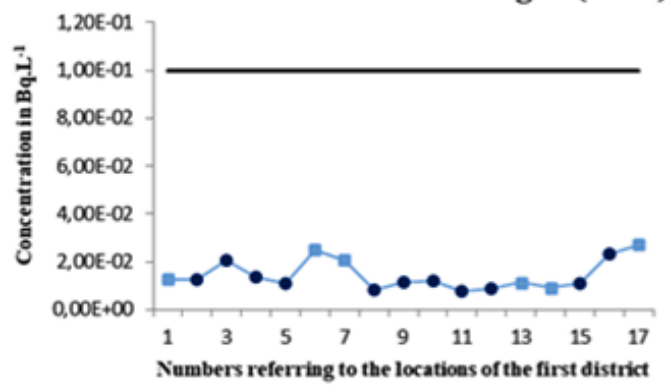

C

Ra-228 - $3^{\circ}$ District of Angra (2016)

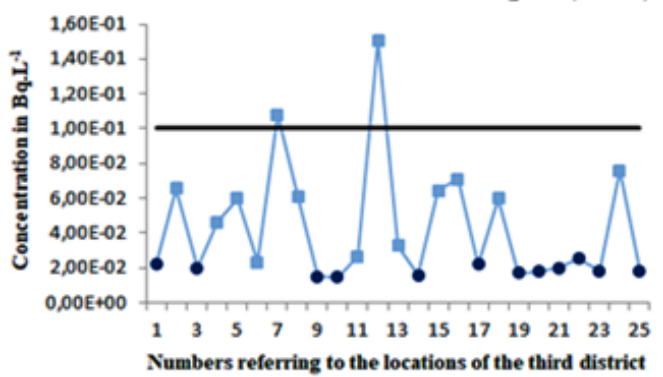

Ra-228 - $3^{\circ}$ District of Angra (2018)

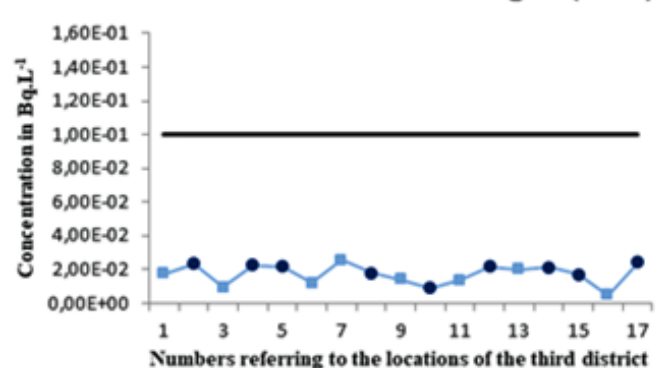

B

Ra-228 - $2^{\circ}$ District of Angra (2016)

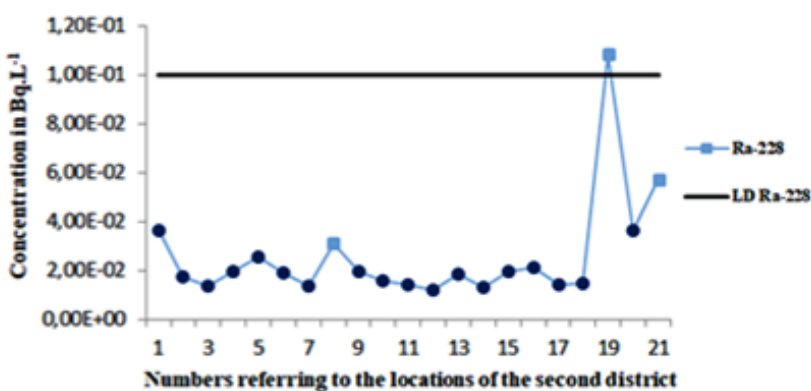

Ra-228 - $2^{\circ}$ District of Angra (2018)

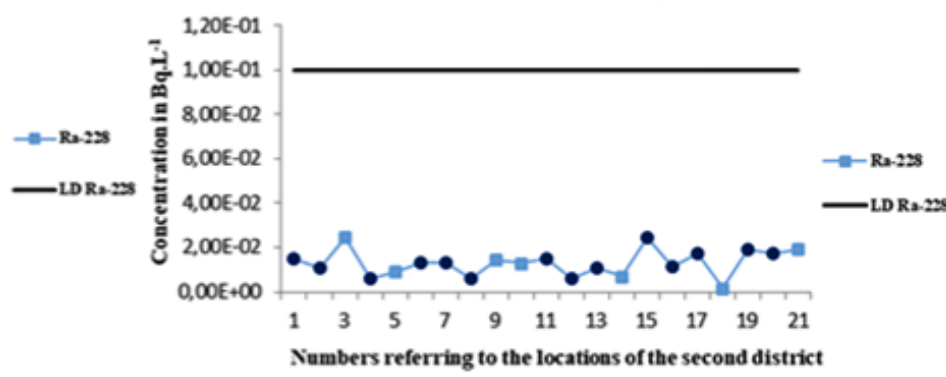

D Ra-228 - $4^{\circ}$ District of Angra (2016)

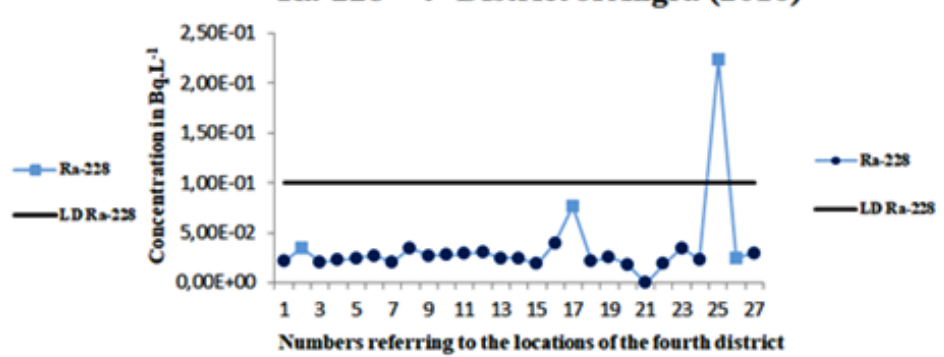

Ra-228 - $4^{\circ}$ District of Angra (2018)

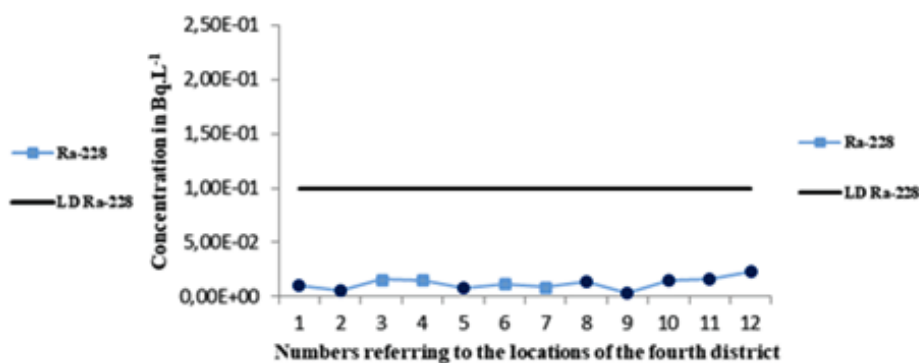

Figure 3: Graphs of Ra-228 concentrations of water samples collected in April 2016 and in November 2018 in the first district (A), the second district $(B)$, the third fistrict $(C)$ and the fourth district (D) of Angra dos Reis. 
The numbers referring to the locations of the samples (x-axis) collected in 2016 and 2018 are not the same, as in 2018 it was not possible to perform the collection due to the lack of security in some areas.

To calculate the detection limit of the method for each radionuclide, the background of the detectors was considered, with the highest value. A sample with a reading of three times the highest value background is simulated. These values are placed in the "Analysis" program to calculate the concentration value.

The detection limit value of the method found was $0.013 \mathrm{~Bq} \mathrm{~L}^{-1}$ for $\mathrm{Ra}-226$ and $0.1 \mathrm{~Bq} \mathrm{~L}^{-1}$ for Ra-228.

Differences were observed in the concentrations and values below the detection limit of the equipment found and this is due to the chemical yield and the background value, which are different for each sample.

In the proportional ultra-low background counter, samples are measured in 10 different detectors and, consequently, each detector has a background value. All values found were very low and very similar, being in the order of $10^{-1}, 10^{-2}$ and $10^{-3}$. The results even above the detection limit of the method were also low.

For further understanding, Table 1 shows the highest and lowest concentrations of Ra-226 and Ra-228 in each district of the collections carried out in April 2016 and November 2018.

Table 1: Range of Ra-226 and Ra-228 activity concentrations in each district. Activity

Concentration $\quad$ First District $\quad$ Second District $\quad$ Third District $\quad$ Fourth District

$\left(\mathrm{Bq} \mathrm{L}^{-1}\right)$

\begin{tabular}{llllll}
\hline \multirow{2}{*}{ Ra-226 } & 2016 & $0.005-0.031$ & $0.006-0.027$ & $0.007-0.044$ & $0.010-0.057$ \\
& 2018 & $0.003-0.013$ & $0.004-0.021$ & $0.004-0.016$ & $0.002-0.010$ \\
\multirow{2}{*}{ Ra-228 } & 2016 & $0.015-0.041$ & $0.002-0.108$ & $0.014-0.151$ & $0.018-0.224$ \\
& 2018 & $0.007-0.027$ & $0.001-0.024$ & $0.004-0.025$ & $0.002-0.022$ \\
\hline
\end{tabular}


According to the WHO, the activity concentration values cannot exceed $0.5 \mathrm{~Bq} \mathrm{~L}^{-1}$ for Ra-226 and $1 \mathrm{~Bq} \mathrm{~L}^{-1}$ for Ra-228 [7]. Thus, when comparing the results of activity concentrations of Ra-226 and Ra-228, it was found that the values did not exceed the reference level adopted by the WHO.

The concentration of Ra-226 activities from all points analyzed in the period of April 2016 ranged from 0.005 to $0.057 \mathrm{~Bq} \mathrm{~L}^{-1}$. In the period of November 2018, the activity concentrations of this radionuclide, from all points analyzed, ranged from 0.002 to $0.021 \mathrm{~Bq} \mathrm{~L}^{-1}$.

The concentrations of Ra-228 activities from all points analyzed in April 2016 and in November 2018 ranged from 0.002 to $0.224 \mathrm{~Bq} \mathrm{~L}^{-1}$ and 0.001 to $0.027 \mathrm{~Bq} \mathrm{~L}^{-1}$, respectively. It was noted that the concentrations decreased from one period to the next and a possible explanation would be that the collections carried out in November 2018 were made during the rainy season.

\subsubsection{Determination of $\mathbf{P b}-210$}

The Figure 4 shows the $\mathrm{Pb}-210$ concentrations of the water samples collected in the periods of April 2016 and November 2018, from the four districts of Angra dos Reis, where the concentrations are represented by the square markers in blue. The continuous line refers to the detection limit of the method and the circular markers in dark blue are the values below the detection limit equipment. 
A

Pb-210 - $1^{\circ}$ District of Angra (2016)

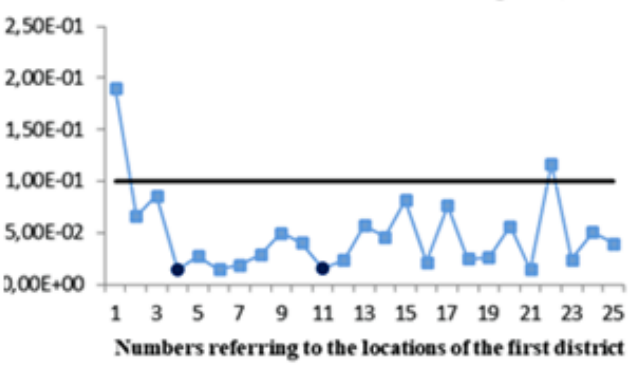

Pb-210 - $1^{\circ}$ District of Angra (2018)

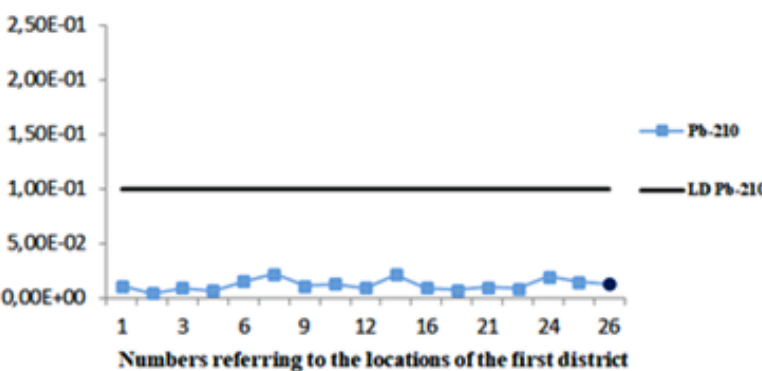

C Pb-210 $-3^{\circ}$ District of Angra (2016)

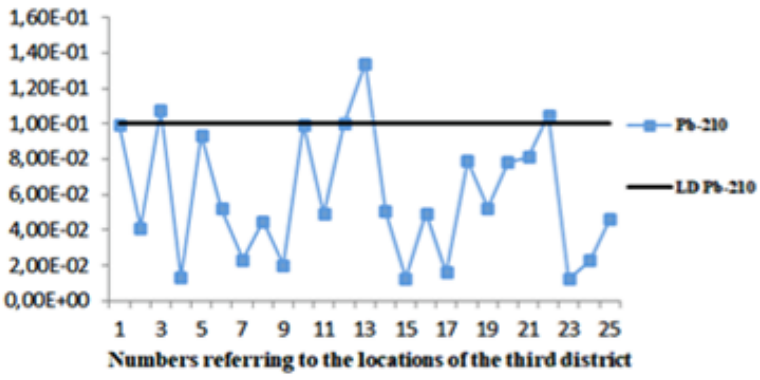

Pb-210 - $3^{\circ}$ District of Angra (2018)
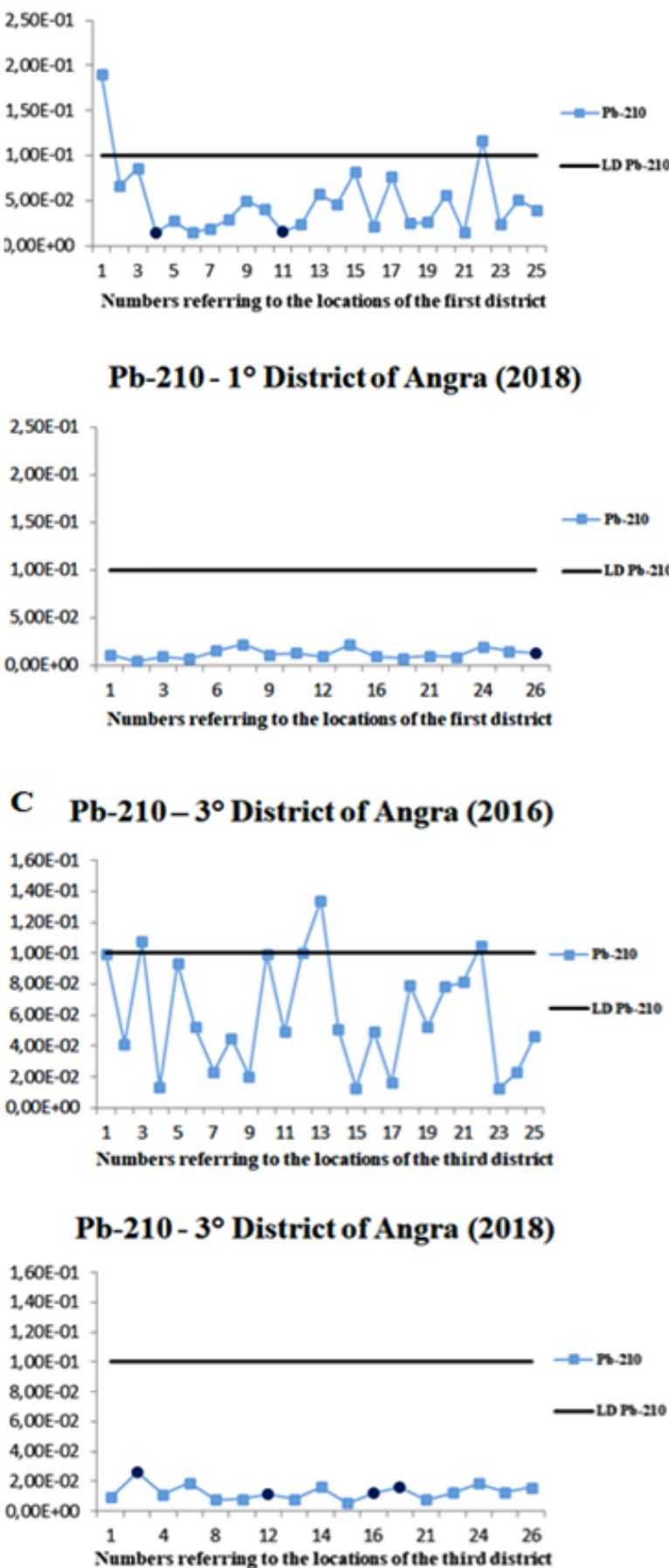

\section{B}

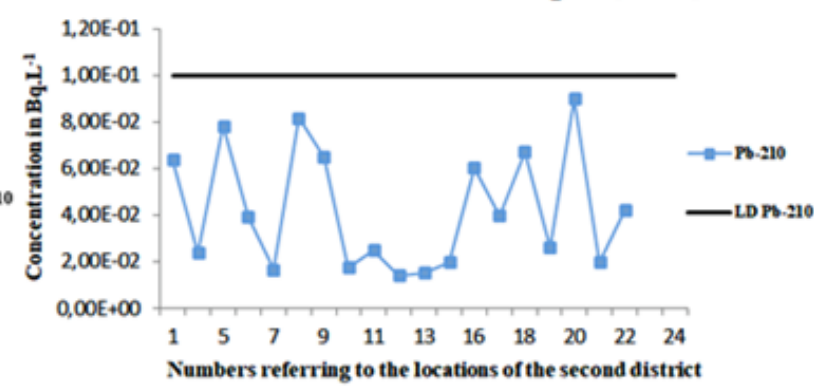

Pb-210 - 2 ${ }^{\circ}$ District of Angra (2018)

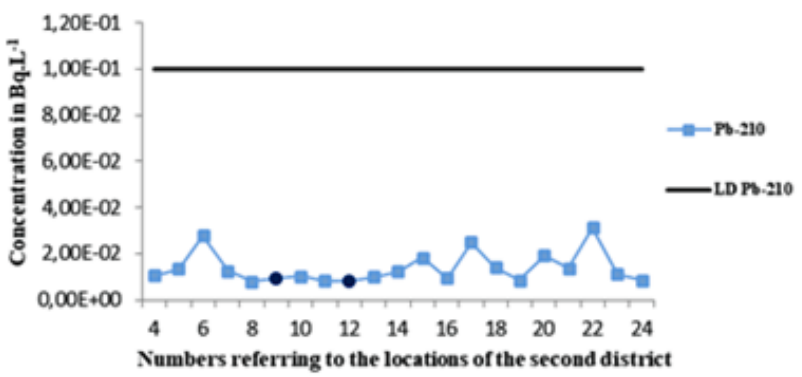

D Pb-210 $-4^{\circ}$ District of Angra (2016)

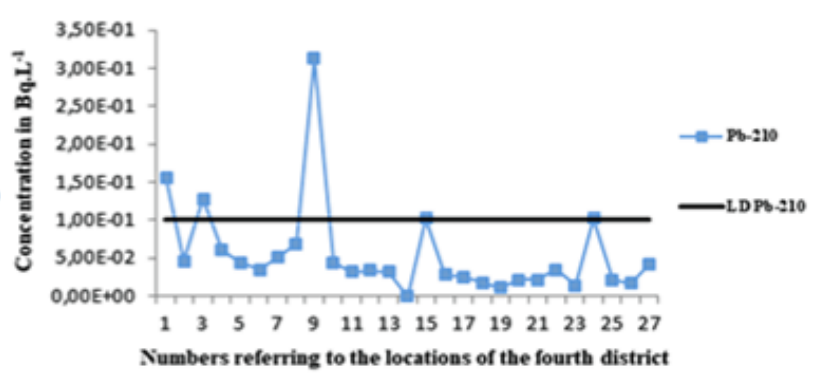

Pb-210 - $4^{\circ}$ District of Angra (2018)

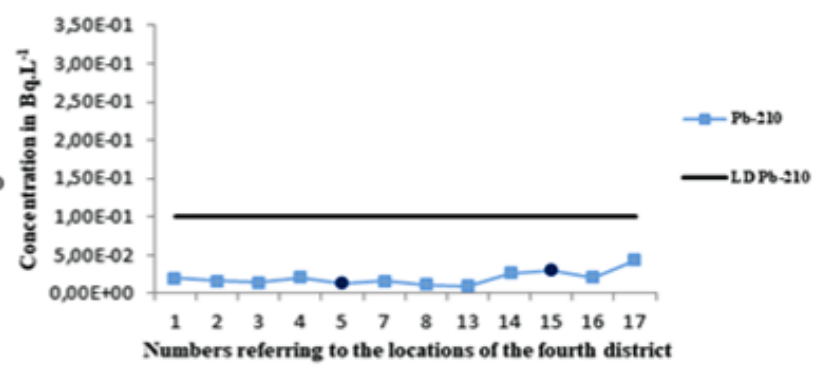

Figure 4: Graphs of Pb-210 concentrations of water samples collected in April 2016 and in November 2018 in the first district $(A)$, the second district $(B)$, the third fistrict $(C)$ and the fourth district (D) of Angra dos Reis. 
The calculation for the detection limit of the method was performed in a similar way to that of the radio. For $\mathrm{Pb}-210$ the detection limit was equal to $0.1 \mathrm{~Bq} \mathrm{~L} \mathrm{~L}^{-1}$.

The chemical yields and the different background values can be reasons for the different values observed in the figure above.

All values found were very low and similar, being in the order of $10^{-1}, 10^{-2}$ and $10^{-3}$. As well as the radionuclides previously mentioned, points above the detection limit of the method were obtained.

For better understanding, Table 2 shows the highest and lowest concentrations of $\mathrm{Pb}-210$ in each district of the collections carried out in April 2016 and November 2018.

Table 2: Range of $\mathrm{Pb}-210$ activity concentrations in each district.

\section{Activity}

Concentration First District Second District $\quad$ Third District $\quad$ Fourth District

$\left(\mathbf{B q} \mathbf{L}^{-1}\right)$

$\begin{array}{lllll}\mathrm{Pb}-210(2016) & 0.014-0.191 & 0.012-0.090 & 0.012-0.134 & 0.011-0.314 \\ \mathrm{~Pb}-210(2018) & 0.004-0.021 & 0.008-0.031 & 0.005-0.026 & 0.008-0.042\end{array}$

The values of the concentrations found are lower than the maximum recommended of the $\mathrm{Pb}-$ 210 in water for human consumption, which is $0.1 \mathrm{~Bq} \mathrm{~L}^{-1}$, according to the WHO [7].

The concentrations of $\mathrm{Pb}-210$ activities from all points analyzed in the period of April 2016 and November 2018 ranged from 0.011 to $0.314 \mathrm{~Bq} \mathrm{~L}^{-1}$ and 0.004 to $0.042 \mathrm{~Bq} \mathrm{~L}^{-1}$, respectively. Possibly, due to the rainy period of the second collection, the values of the concentrations of 2018 were lower than those of 2016, as well as Ra-226 and Ra-228.

\subsection{Gamma spectrometry}

The values of the detection limits of Cs-134 and Cs-137 of the samples collected in April 2016 in the four districts of Angra dos Reis are shown in Figure 5. In the graphs, the values of the detection limits of Cs- 134 and Cs-137 are represented by square markers in blue and triangular 
markers in red, respectively. The continuous and dashed lines correspond to the detection limits of the method of these radionuclides.

There are no results from the samples collected in the period of November 2018, as the results found previously, in April 2016, were all below the detection limit. 
A

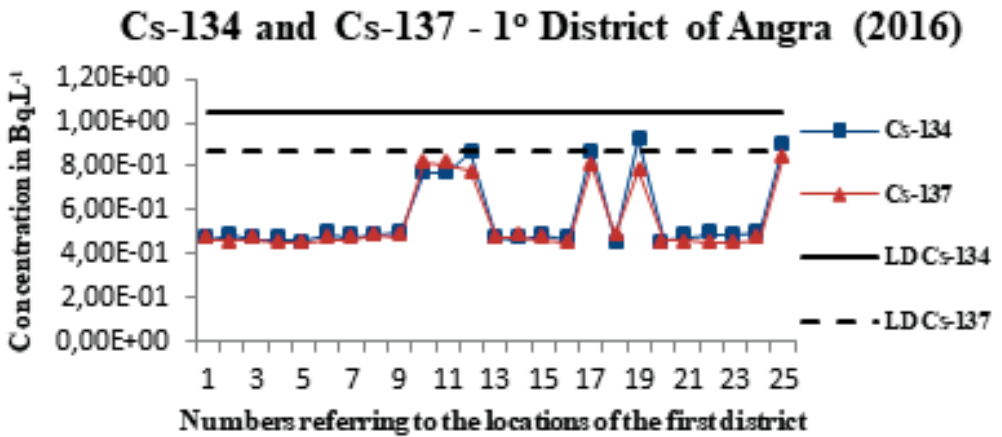

B

Cs-134 and Cs-137 - $2^{\circ}$ District of Angra (2016)

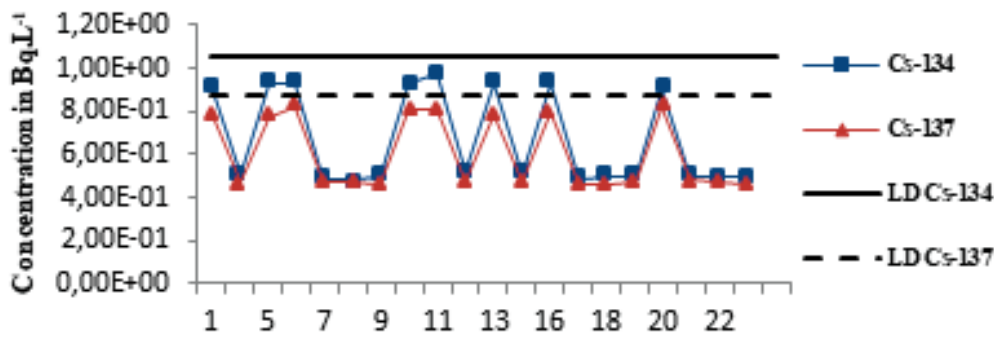

Numbers referring to the locations of the second district

C

Cs-134 and Cs-137 - $3^{\circ}$ District of Angra (2016)

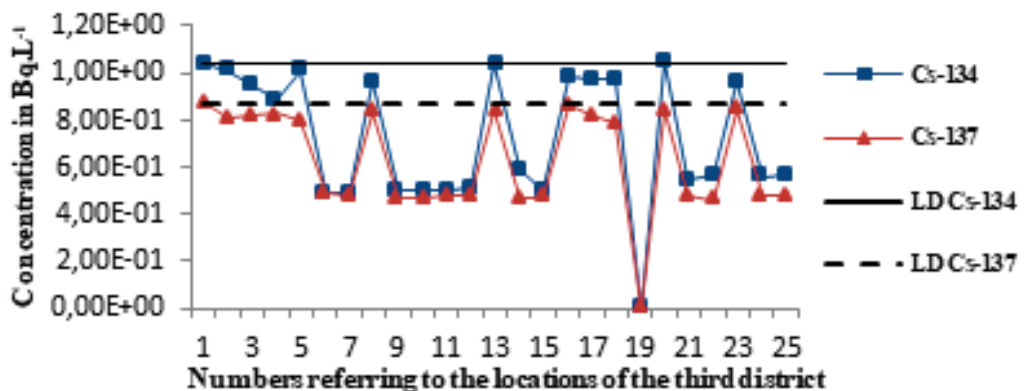

D

Cs-134 and Cs-137 - $4^{\circ}$ District of Angra (2016)

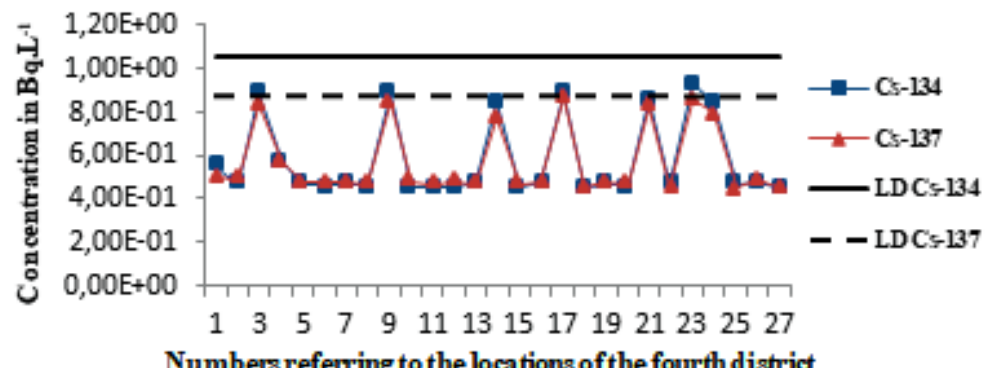

Figure 5: Graphs of Cs-134 and Cs-137 concentrations of water samples collected in April 2016 in the first district $(A)$, the second district $(B)$, the third fistrict $(C)$ and the fourth district $(D)$ of Angra dos Reis. 
The Cs-134 and Cs-137 values for all points analyzed in the period of April 2016 were lower than the detection limit. Thus, there was no contribution of these radionuclides in the waters to human consumption.

The differences in the values found were due to the use of two different detectors (GC2020 and well detector) and, consequently, with different detection limits. The values found below refer to the samples that were made in the well detector and those made in the GC2020 detector are a little higher up. The well detector has an efficiency of 40\%, while the GC2020 has an efficiency of $20 \%$. So, the higher the efficiency of the detector, the lower the detection limit of the equipment.

The detection limit of the method for each radionuclide was defined as the highest value of the detection limit of the equipment, thus the detection limit for Cs-134 was $1.05 \mathrm{~Bq} \mathrm{~L}^{-1}$ and for Cs-137 was $0.87 \mathrm{~Bq} \mathrm{~L}^{-1}$.

As they are artificial radionuclides, the values will only be established in case of emergency [1].

\subsection{Inductively coupled plasma mass spectrometry analysis}

In the graphs of Figures 6 and 7, the concentrations of U-238 and Th-232 of the samples collected in November 2018 are represented by the markers and the continuous lines correspond to the radionuclide detection limits mentioned above.

There are no results from the samples collected in the period of April 2016, as at the time the ICP-MS equipment was not operational. 
A

U-238 - $1^{\circ}$ District of Angra (2018)

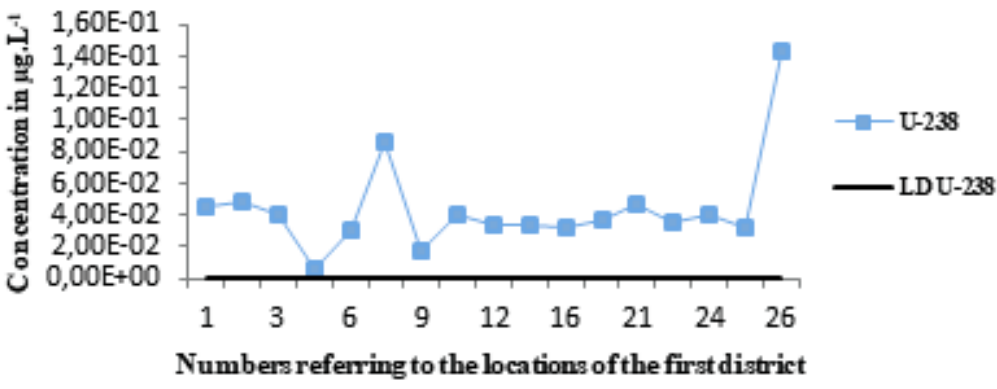

B

U-238 - $2^{\circ}$ District of Angra (2018)

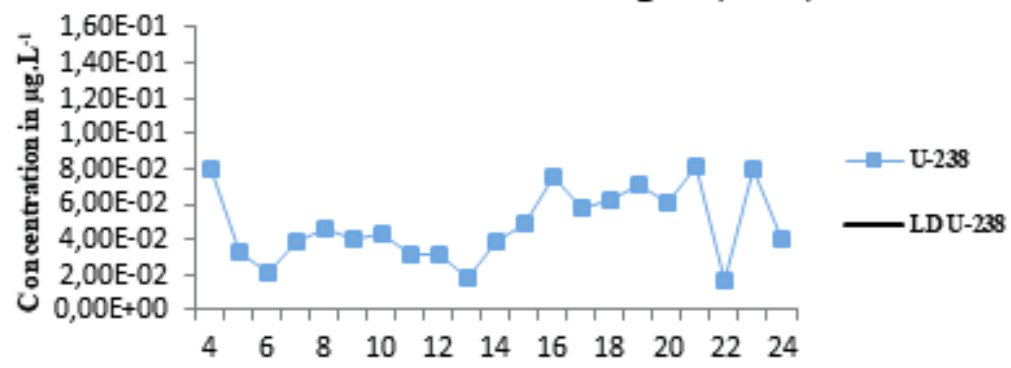

Numbers referring to the locations of the second district

C

U-238 - $3^{\circ}$ District of Angra (2018)

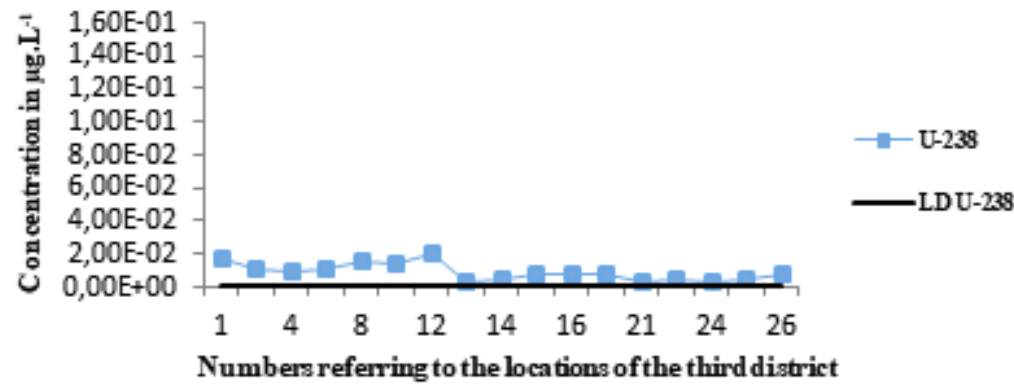

D

U-238 - $4^{\circ}$ District of Angra (2018)

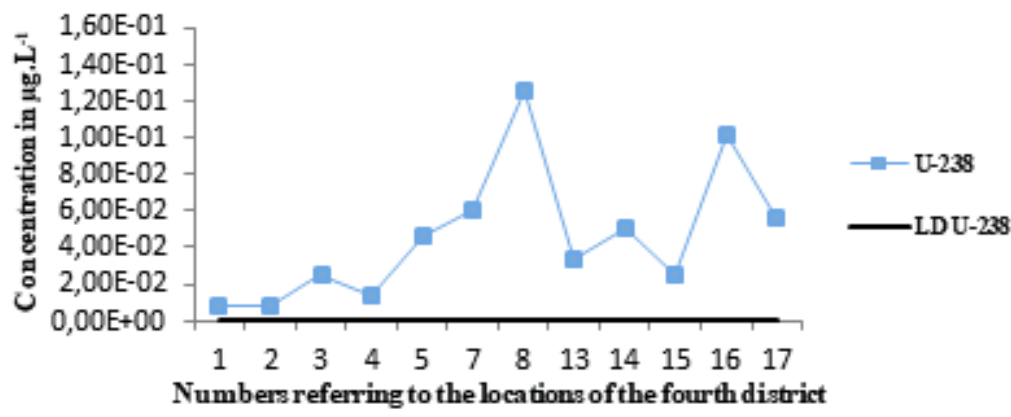

Figure 6: Graphs of U-238 concentrations of water samples collected in November 2018 in the first district (A), the second district (B), the third fistrict $(C)$ and the fourth district $(D)$ of Angra dos Reis. 
A

Th-232 - $1^{\circ}$ District of Angra (2018)

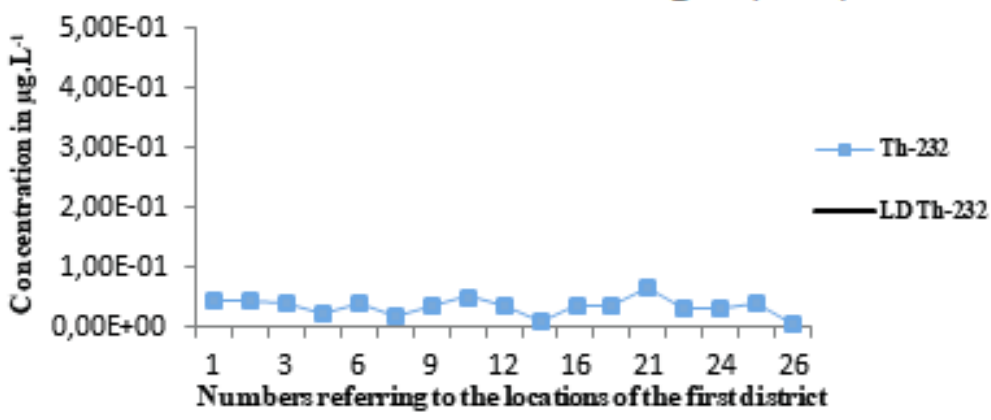

B

Th-232 - $2^{\circ}$ District of Angra (2018)

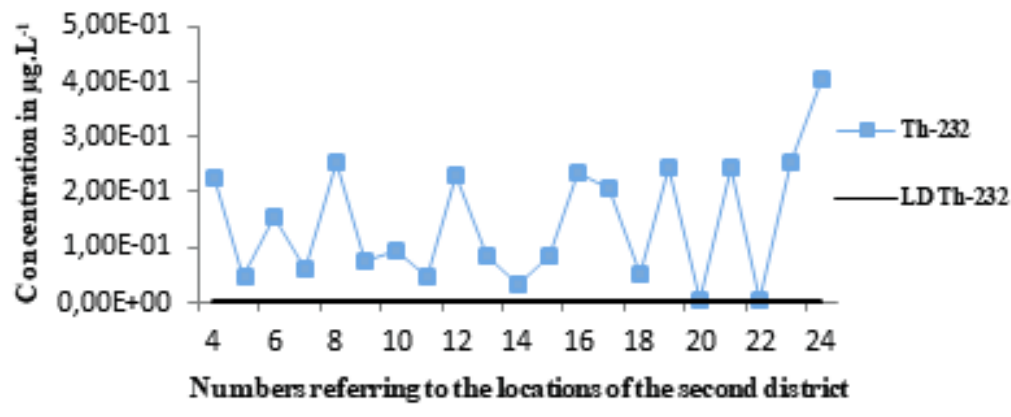

C

Th-232 - $3^{\circ}$ District of Angra (2018)

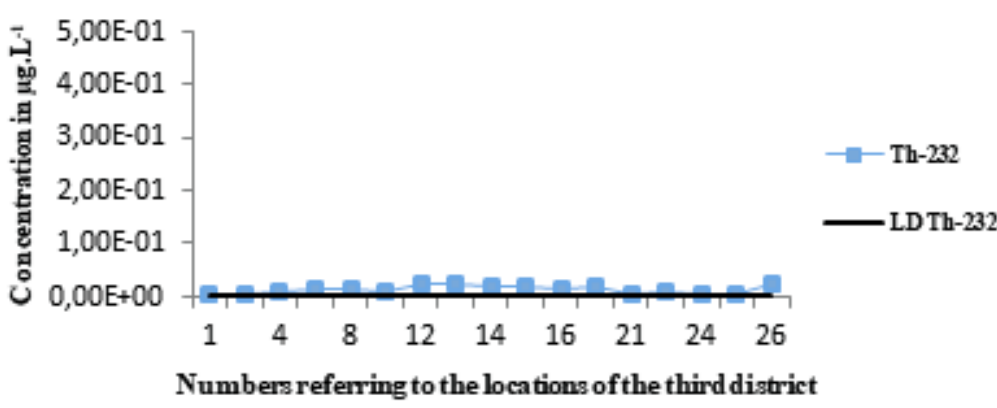

D

Th-232 $-4^{\circ}$ District of Angra (2018)

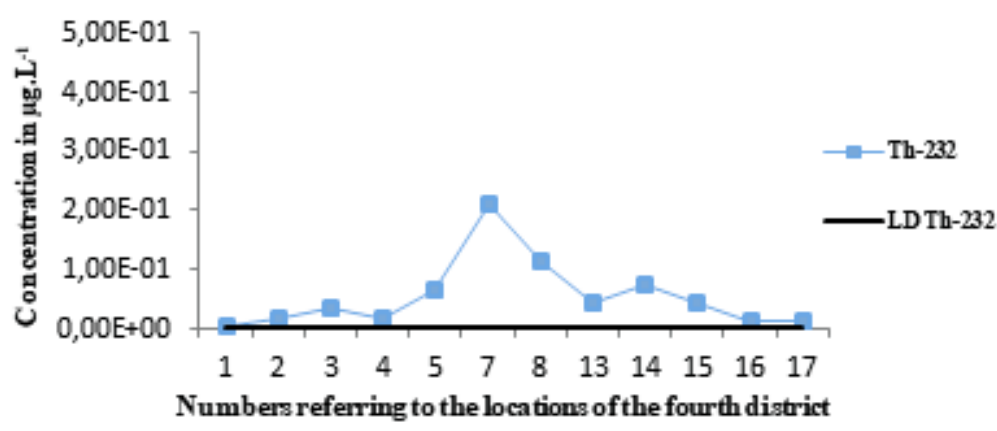

Figure 7: Graphs of Th-232 concentrations of water samples collected in November 2018 in the first district (A), the second district (B), the third fistrict $(C)$ and the fourth district $(D)$ of Angra dos Reis. 
The detection limits of U-238 and Th-232 were informed by the Syngistix program itself and because they are very low, a value of 0.001 for both, the line is imperceptible in most graphics.

As the detection limits were low, all samples had their respective concentrations measured. And even being above the limit, these values are low.

The highest and lowest concentrations of uranium and thorium in each district are highlighted in Table 3.

Table 3: Range of U-238 and Th-232 activity_concentrations in each district. Activity

Concentration First District Second District $\quad$ Third District $\quad$ Fourth District $\left(\mu \mathrm{g} \mathrm{L^{-1 }}\right)$

$\begin{array}{ccccc}\text { Uranium (U-238) } & 0.006-0.142 & 0.016-0.082 & 0.002-0.020 & 0.008-0.126 \\ \text { Thorium (Th-232) } & 0.004-0.066 & 0.004-0.402 & 0.002-0.023 & 0.004-0.210\end{array}$

The uranium and thorium activity concentrations of all the analyzed points ranged from 0.002 to $0.142 \mu \mathrm{g} \mathrm{L}{ }^{-1}$ and 0.002 to $0.402 \mu \mathrm{g} \mathrm{L}^{-1}$, respectively.

Comparing the U-238 concentrations found, they did not exceed the reference level of $30 \mu \mathrm{g} \mathrm{L}^{-1}$ adopted by Ministry of Health regarding radioactivity [6]. For Th-232, although there is not activity concentration established by CONAMA, the values found are within the range of 0.01 and $1.0 \mu \mathrm{g} \mathrm{L}^{-}$ 1 , determined by the literature for surface and groundwater [5].

\section{CONCLUSION}

The activity concentrations of Ra-226, Ra-228, Pb-210, Cs-134, Cs-137, U-238 and Th-232 were determined in water samples collected in the four districts of Angra dos Reis in two different periods.

The results found for Ra-226 and Ra-228 were, in the majority, below the detection limit of the method. The same can be seen in the results of $\mathrm{Pb}-210$. For artificial radionuclides, Cs-134 and Cs137, all values found were lower than the detection limits of the method. In the case of U-238 and 
Th-232, the results found were above the detection limit, but low and similar values as the other radionuclides.

All results are within the range recommended by WHO, Ministry of Health and CONAMA regarding the radioactivity of each radionuclide. So it is possible to affirm that the presence of these radionuclides in the collected waters is natural and with levels that are not harmful to human health.

In general, the radionuclides present in the collected waters are mainly of natural origin, due to the minerals of the rocks and dissolution of gases. But other sources of radioactivity can also be considered, such as those caused by the "fallout". Because of this, water sources must be monitored to ensure that they have a low level of radioactive concentration.

It was possible to know the values of the main natural radionuclides in the waters of the region and in the event of an accident, this work will be used as a reference. Based on the results, the presence of radionuclides in the water samples is due to the nature of the water in the districts and not to the existence of the nuclear power plant.

Regarding the calculation of uncertainty, as most of the results were lower than the detection limit of the method, the calculation did not fit and the few that were above, even so, were below the detection limit of the method. 


\section{ACKNOWLEDGMENT}

The authors thank the Department of Environmental Analysis (DIRAD) for the opportunity to carry out this work. To José Antonio Gonçalves for the transport of samples. To the technical analyst Carlos Henrique and the Scientific Initiation students, for their help during the execution of the radiochemical analysis. Student Amanda Bassaliano, for carrying out the analyzes at ICP-MS. To Dr. Fernando Ribeiro, for the radiometric analysis. To Igor Caldeira Pinto for review. To CNEN for granting the scholarship.

\section{REFERENCES}

[1] GONÇALVES, M. F. Monitoração de radionuclídeos em águas para consumo humano do Município de Angra dos Reis, Dissertação de Mestrado, Instituto de Radioproteção e Dosimetria - Comissão Nacional de Energia Nuclear, Rio de Janeiro, RJ, Brasil, 2020.

[2] CARDOSO S. N. M.; TAVARES, P. G.; BARBOZA, E. A monitoração radiológica ambiental da Central Nuclear Almirante Álvaro Alberto, In: CONGRESSO BRASILEIRO DE QUÍMICA, 2011, São Luís.

[3] GOMES, F. C.; GODOY, J. M.; GODOY, M. L. D. P.; CARVALHO, Z. L.; LOPES, R. T.; SANCHEZ-CABEZA, J. A.; OSVATH, I.; LACERDA, L. D. Geochronology of anthropogenic radionuclides in Ribeira Bay sediments. Journal of Environmental Radioactivity, v. 102, n. 9, p. 871-876, 2011.

[4] SECRETARIA MUNICIPAL DE SAÚdE DE ANGRA DOS REIS. Plano Municipal de Saúde de Angra dos Reis 2018 - 2021. Available at: <https://www.angra.rj.gov.br/downloads/SSA/Plano_municipal_de_saude_2018-2021.pdf>. Last accessed: 15 Ago. 2018.

[5] LAURIA, D. C.; VEIGA, L. H. S.; FRANKLIN, M. R. Radioatividade em água potável: Ocorrência, regulamentação e aspectos de proteção radiológica, $1^{\text {st }}$ ed., Rio de Janeiro: Instituto de Radioproteção e Dosimetria, 2014. 
[6] MS - Ministério da Saúde. Procedimentos de controle e de vigilância da qualidade da água para consumo humano e seu padrão de potabilidade. Portaria MS nº. 2.914, 2011, 34p.

[7] WHO - World Health Organization. Guidelines for Drinking-water Quality, Fourth Edition. WHO: Geneva, 2011, 564p.

[8] RIBEIRO, F. C. A.; LAURIA, D. C.; RIO, M. A. P.; CUNHA, F. G.; SOUSA, W. O.; LIMA, E. A. M.; FRANZEN, M. Mapping soil radioactivity in the Fernando de Noronha archipelago, Brazil. J Radioanal Nucl Chem, v. 311, p. 577-587, 2017.

[9] KANISCH, G.; RIETH, U.; KRÜGER. Procedure for determining the specific activities of radionuclides in fish by gamma spectrometry. G- $\boldsymbol{\gamma}$-SPEKT-FISCH-01, 2016. 